\title{
Fenomena Jerebu antara Perspektif Quran dan Sains Moden
}

(Haze Phenomenon between Quran and Modern Science Perspectives)

\section{AHMad Yunus MoHD NOOR*, Nor AzILAH AbDUl WAHAB \& ASMILYIA MOHD MOKHTAR}

\section{ABSTRAK}

Jerebu merupakan fenomena pencemaran udara yang memberi impak negatif kepada kesihatan dan kegiatan sosial masyarakat serta negara. Isu jerebu dibincangkan dalam al-Quran iaitu sura al-Dukhan secara menyeluruh. Kertas ini bertujuan menganalisis perbahasan berkaitan masalah jerebu yang disebutkan oleh al-Quran dan tafsiran para sarjana Islam dalam konteks dan sudut pandang Islam. Kertas ini turut membincangkan punca dan kesan berlakunya masalah jerebu daripada perspektif sains. Kajian ini menggunakan kaedah kualitatifiaitu dengan merujuk kepada kaedah transdisiplin daripada perspektif Quran dan sains. Keputusan kajian mendapati terdapat tafsiran para sarjana Islam yang mentafsirkan surah al-Dukhan dan fenomena jerebu yang berlaku pada zaman Rasullullah SAW. Ia merupakan azab dan seksaan kepada kaum Musyrikin disebabkan oleh perbuatan mereka yang enggan menerima ajaran Islam. Fenomena jerebu merupakan peringatan Allah dan pengajaran kepada umat manusia supaya sentiasa taat kepada perintah dan meninggalkan segala larangan-Nya di samping bersama-sama menjaga keharmonian dan kesejahteraan alam semesta ini. Manakala para saintis pula mendapati fenomena jerebu yang berlaku adalah berpunca daripada asap dan habuk kesan daripada aktiviti antropogen dan semula jadi serta kesannya terhadap kesihatan tubuh badan manusia yang mengakibatkan hidung berair, masalah kulit, mata terasa pedih dan berair, batuk, sakit kerongkong, kesukaran untuk bernafas dan kesakitan di bahagian dada.

Kata kunci: Ahli sains; jerebu; Quran; sains; tafsiran

\section{ABSTRACT}

Haze is an atmospheric phenomenon contributing negative impacts on the human health and social activities of the community and the country. Haze issue has been comprehensively discussed in the Quran; sura al-Dukhan. This paper aimed to analyze the haze issue which has been mentioned by the Quran and Islamic scholars in their interpretation and Islamic contextual perspective. This paper also discusses the causes and effects of the occurrence of the haze problem from the scientific perspective. This study used qualitative methods, by referencing to transdisciplinary method from the Quran and Science perspectives. The study found that interpretations of the sura al-Dukhan and haze phenomenon that occurs at the time of the Prophet Muhammad ( $P B U H)$ have been widely interpreted by Islamic scholars. It was an agony and torture to the polytheists due to their actions which refused to accept the teachings of Islam. Haze phenomenon is a reminder of God and lesson the people to always obey commands and right conduct and forbid wrongdoing as well as to jointly maintain the harmony and prosperity of the universe. While the scientists found that the haze phenomenon that occurs is due to the smoke and dust cause by antropogenic and natural activities as well as its impact on the human health causes runny nose, skin problem, burning and watery eyes, coughing, sore throat, shortness of breath and chest pain.

Keywords: Haze; interpretation; Quran; science; scientist

\section{PENGenalan}

\section{JEREBU DARIPADA PERSPEKTIF AL-QURAN}

Dukhan daripada segi bahasa menurut kamus Miftah membawa maksud satu keadaan yang berasap atau berkabut. Pendapat ini disokong oleh Ibnu Manzur dalam Lisan alArab yang mengatakan bahawa dukhan daripada segi bahasa membawa maksud asap atau debu yang bertebaran di udara dan juga membawa maksud asap yang sangat tebal. Beliau membuat perumpamaan dengan mengatakan asap tersebut seakan-akan makanan atau daging yang dimasak dan mengeluarkan asap sehinggalah makanan tersebut berubah bau dan rasanya (Ibnu Manzur 2012).
Dukhan atau jerebu adalah merupakan satu keadaan yang kering dan antara langit dan bumi dipenuhi dengan asap yang menyelubungi permukaan bumi. Asap yang meliputi tersebut dapat membuatkan seseorang berasa pedih mata dan jarak penglihatan menjadi kabur. Dukhan juga dikaitkan dengan penderitaan seperti kelaparan, dahaga dan kesusahan yang merupakan salah satu daripada azab Allah yang pedih ke atas mereka yang ingkar akan perintah serta larangan-Nya (Fakhruddin 2000).

Menurut Al-Suyuti (2000) pula, dukhan dapat dilihat dengan menggunakan pandangan mata kasar dan ia dikatakan berwarna putih dan mampu membuatkan pemandangan terhadap suatu tempat ke suatu tempat 
itu menjadi kabur. Dukhan jika dilihat daripada sudut pengajaran yang dapat diambil daripada faktor kejadiannya ia merupakan azab atau seksaan Allah kepada manusia yang sering alpa dengan kehidupan duniawi sehingga melupakan tanggungjawab sebagai seorang hamba Allah di muka bumi ini. Manakala Fuad Abdul Baqi (2002) menyatakan bahawa ad-Dukhan disebutkan di dalam alQuran sebanyak dua kali iaitu pada Surah ad-Dukhan ayat 10 dan Surah Fussilat ayat 11. Allah berfirman:

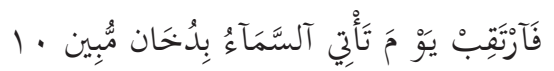

Maka tunggulah pada hari ketika langit membawa kabut yang tampak jelas (10) (Quran 44:10).

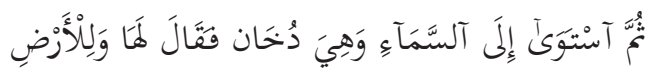

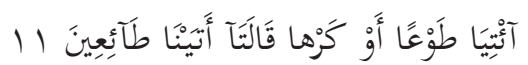

Kemudian Dia menuju ke langit dan langit itu masih seperti asap, lalu Dia berfirman kepadanya dan kepada bumi, "Datanglah kamu berdua menyahut perintah-Ku dengan patuh atau terpaksa." Keduanya menjawab, kami datang dengan patuh" (Quran 41:11).

Sa'̄̄d Hawwā(1985) dalam penulisannya iaitu Kitab alAsās fī al-Tafsīr menjelaskan keadaan kejadian dunia yang disebutkan pada ayat 11 Surah Fussilat. "Sesungguhnya di sana memang sudah ada suatu keyakinan bahawa sebelum terjadinya bintang-bintang, keadaan adalah di dalam bentuk gas nebula seperti asap. Pandangan seperti ini boleh dianggap sahih kerana begitu hampir dengan hakikat kalimah dukhan di dalam al-Quran".

Dalam tafsir al-Mubin pula, Salahuddin dan Omar (2009) mendatangkan pendapat Ibnu Katsir yang menyatakan perkataan Dukhan atau asap yang dimaksudkan di dalam ayat ini ialah wap air yang keluar ketika bumi diciptakan. Menurut Salahuddin dan Omar (2009) lagi, Al-Zamakhshari pula berpendapat bahawa kata-kata ini adalah sebagai kiasan sahaja iaitu apabila Allah hendak menciptakan langit dan bumi, lalu Allah berfirman kepada keduanya untuk memberitahu bahawa Dia hendak menciptakannya. Langit dan bumi tidak membantah dengan apa yang diperintahkan dan tidak ubah seperti orang suruhan yang sentiasa patuh pada suruhan tuannya.

Sayyid Qutb menyokong pendapat yang mengatakan bahawa ayat tersebut menunjukkan kepatuhan makhluk ciptaan Allah iaitu langit dan bumi terhadap perintah Tuhannya. Tambah beliau lagi, ayat tersebut juga adalah sebagai pengajaran kepada umat manusia untuk tunduk dan patuh terhadap perintah Allah seperti mana yang digambarkan dengan kepatuhan langit dan bumi (Sayyid Qutb 2000).

Asy-Syaukani (2012) pula memetik pendapat Ibnu Jarir yang meriwayatkan asap yang dimaksudkan di dalam ayat al-Quran tersebut adalah asap daripada neraka jahanam dan asap tersebut dikatakan berwarna hitam.
Prof Dr Hamka memberi contoh dalam membahaskan ayat tersebut dengan mengibaratkan seperti manusia cuba untuk membakar kayu yang basah dan api sukar untuk menyala hanya asapnya sahaja yang akan keluar sehingga mata kita berair akibat daripada asap yang mengepul itu (Hamka 1981).

Bagi pendapat Ibnu Katsir (2003), pada zahir ayat al-Quran tersebut jelas menunjukkan adanya asap atau jerebu yang menutupi langit dan ini berkaitan tandatanda kiamat yang salah satu antara perkara tersebut ialah munculnya ad-Dukhan. Muhammad Hisyam Kabbani (2003) bersetuju dengan pendapat yang mengatakan dukhan adalah merupakan salah satu tanda kemunculan hari kiamat. Beliau juga memasukkan teori-teori sains moden yang menunjukkan bahawa dalam satu luka terbakar yang teruk, organ tubuh, darah dan cairan akan menjadi padat. Organ tubuh yang padat akan menekan organ tubuh lain yang mengandungi cairan seperti telinga sehingga ianya meletus. Beliau mengatakan bahawa asap tersebut boleh terjadi daripada beberapa sumber iaitu gas sulfur yang beracun daripada gunung berapi, asap daripada ladang minyak yang terbakar dan asap daripada letupan nuklear (Kabbani 2003).

Daripada pendapat tersebut, dapat disimpulkan bahawasa perbincangan serta asap yang dikatakan di dalam ayat ini adalah gambaran terhadap balasan Allah di akhirat kelak kepada mereka yang berpaling daripada syariat Allah. Walaupun pada zahir ayat tidak disebutkan berkaitan ad-Dukhan namun didatangkan perkataan lain yang mempunyai maksud yang hampir sama dan ia juga menerangkan berkaitan azab seksa yang telah dijanjikan Allah. Ad-Dukhan mempunyai perbahasan yang sangat panjang dalam kalangan ulama tafsir dan para ilmuan serta wujud beberapa perbezaan pendapat dalam kalangan ulama dalam mentafsirkan ayat tersebut.

Terdapat sebahagian pendapat ulama tafsir yang menyebut bahawa dukhan yang disebutkan telah berlaku pada zaman Rasulullah s.a.w ke atas kaum musyrikin yang tidak mahu patuh akan perintah Allah dan melanggar segala larangan-Nya. Hal demikian dapat dilihat dengan jelas dalam Surah ad-Dukhan ayat 14 apabila Nabi Muhammad s.a.w dituduh menerima ilmu pelajaran daripada seorang yang bukan bangsa Arab bernama Addas yang merupakan golongan Nasrani atau beragama Kristian. Allah berfirman:

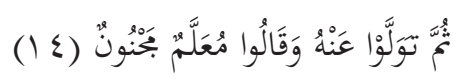

Kemudian mereka berpaling darinya dan berkata, "Dia itu orang yang menerima ajaran (dari orang lain) dan orang gila" (Quran, 44:14).

Pendapat ini difahami daripada sudut zahir ayat yang menyebutkan seakan-akan ia telah pun berlaku. Manakala terdapat pendapat lain yang mendakwa bahawasanya dukhan adalah sesuatu yang belum berlaku dan merupakan salah satu daripada tanda kemunculan hari kiamat. 


\section{JEREBU DARIPADA PERSPEKTIF SAINS}

Jerebu boleh didefinisikan sebagai fenomena pencemaran alam sekitar iaitu ruang udara dipenuhi asap yang mengandungi gas yang berbahaya kepada kesihatan manusia. Kehadiran zarah halus (0.1-1.0 $\mu \mathrm{m}$ diameter) yang tersebar di ruang udara dalam kepekatan yang tinggi dan menyebabkan jarak penglihatan berkurangan. Zarah halus berkenaan adalah daripada campuran aerosol dan asap fotokimia (Mu \& Zhang 2014). Aerosol merupakan zarah yang berpunca daripada pembakaran biojisim dan pembakaran tanah gambut (Khan et al. 2016). Indeks Pencemaran Udara (IPU) merupakan petunjuk kepada tahap kualiti udara. IPU diukur menggunakan pengiraan cadangan Agensi Perlindungan Alam Sekitar Amerika Syarikat (US-EPA) melalui pengiraan sub-indeks berdasarkan lima parameter pencemar udara iaitu partikel halus berdiameter kurang daripada $10 \mu \mathrm{m}\left(\mathrm{PM}_{10}\right)$, sulfur dioksida $\left(\mathrm{SO}_{2}\right)$, nitrogen dioksida $\left(\mathrm{NO}_{2}\right)$, ozon $\left(\mathrm{O}_{3}\right)$ dan karbon monosida (CO). Sub-indeks bagi bahan pencemar individu yang mempunyai nilai yang paling tinggi diambil sebagai bacaan nilai IPU untuk tempoh waktu berkenaan (Dominick et al. 2012). Bahan-bahan pencemar udara turut dipengaruhi dengan parameter meteorogi iaitu suhu, sinaran matahari, kelembapan relatif, hujan serta kelajuan angin (Mahmud \& Ab Llah 2010; Zhang et al. 2015). Jerebu boleh berpunca daripada sumber dalam negeri atau merentasi sempadan. Kebakaran hutan dan tanah gambut di Indonesia terutama di Kalimantan dan Sumatera telah menyebabkan jerebu tersebar ke negara jiran seperti Malaysia dan Singapura (Keywood et al. 2003; Othman et al. 2014).

\section{KAEDAH}

\section{FAKTOR BERLAKUNYA JEREBU}

Fenomena jerebu adalah berpunca daripada pencemaran udara dan telah memberi impak yang besar kepada orang ramai. Kawasan bandar adalah lebih cenderung terjejas semasa kejadian jerebu berbanding kawasan luar bandar. Aktiviti pencemaran udara yang menyumbang kepada fenomena jerebu dapat dibahagikan kepada dua iaitu secara semula jadi dan kegiatan aktiviti antropogenik. Faktor semula jadi yang menyumbang kepada fenomena jerebu adalah letusan gunung berapi, perubahan monsun, fenomena El Niño, panahan petir, ribut debu di kawasan gurun tropika dan kehadiran bioaerosol di dalam udara. Manakala, aktiviti antropogenik pula adalah pembakaran terbuka, pembukaan tanah untuk tujuan pertanian, peningkatan bilangan kenderaan bermotor serta kepesatan kegiatan perindustrian terutama di kawasan bandar (Abdul Rahman 2002). Fenomena jerebu adalah tidak terhad kepada sesebuah negara, malah turut merebak ke negara yang berdekatan berikutan sifat kepulan asap yang tercemar berkenaan sentiasa bergerak. Kehadiran angin turut menyumbang kepada penyebaran asap yang tercemar berkenaan (Lee et al. 2016).
Beberapa kejadian letusan gunung berapi telah menyebabkan fenomena jerebu berlaku. Antaranya ialah Gunung Pinatubo di Filipina (Soleiman et al. 2003) dan Gunung Berapi Kilauea di Kepulauan Hawai'i (Tam et al. 2016). Letusan gunung berapi berkenaan telah membebaskan sulfur dioksida $\left(\mathrm{SO}_{2}\right)$ yang seterusnya berinteraksi dengan wap air untuk menghasilkan jerebu berasid dikenali sebagai 'vog'. Perubahan monsun dan El Niño merupakan faktor penting dalam menentukan arah jerebu kerana monsun mengubah laluan perjalanan bahan pencemar dan El Niño meningkatkan kekerapan pembakaran hutan. El Niño merupakan fenomena atau keadaan cuaca panas melampau yang disebabkan oleh pemanasan permukaan lautan pasifik dan telah mengubah cuaca menjadi panas dan kering serta mengurangkan jumlah penurunan hujan. Ketidakhadiran hujan dan cuaca kering semasa El Niño menjadi faktor penggalak kepada peningkatan kejadian jerebu. Cuaca panas melampau yang sering berlaku di kawasan hutan hujan tropika juga menyumbang kepada kejadian jerebu. Ini disebabkan oleh tumbuhan yang terlampau kering terbakar dengan sendirinya dan cuaca kering memudahkan api merebak dengan lebih cepat (Noor Azilawati 2007). Selain itu, kejadian panahan petir turut menyebabkan fenomena jerebu iaitu api yang terhasil daripada panahan petir berkenaan boleh menyebabkan hutan terbakar terutama semasa musim kering melampau atau kemarau. Ribut debu yang sering berlaku di kawasan gurun tropika turut menyumbang kepada fenomena jerebu. Ribut jerebu berkenaan boleh membawa zarah dan bahan tercemar jauh daripada sumber asal (Goudie 2014; Li et al. 2015a). Akhir sekali, bioaerosol turut menyumbang kepada pengurangan tahap kualiti udara seterusnya menjadi antara faktor kejadian jerebu. Bioaerosol ditakrifkan sebagai zarah biologi di atmosfera iaitu zarah bawaan udara atau molekul besar yang membawa organisma hidup atau dilepaskan daripada organisma hidup seperti bakteria, kulat, virus dan debunga (Li et al. 2015b).

Faktor dominan yang menyumbang kepada kejadian jerebu adalah pembakaran hutan secara berleluasa. Fenomena jerebu yang berlaku di Malaysia adalah berpunca daripada kebakaran hutan yang meliputi kawasan sekitar Sumatera Utara, Riau dan Kalimantan di Indonesia. Hampir $60 \%$ daripada zarah dan $\mathrm{CO}_{2}$ di dalam asap dan jerebu adalah berpunca daripada kebakaran tanah gambut dan 20\% daripada pembakaran hutan. Kebakaran tersebut berpunca daripada amalan pembakaran secara terbuka oleh petani di kawasan berkenaan bagi menjalankan aktiviti pertanian pindah (Khan et al. 2016; Yong \& Peh 2014). Kebakaran tanah gambut kebiasaannya kebakaran di bawah tanah dan ia sukar untuk dipadamkan. Asap daripada kebakaran berkenaan tersebar sehingga melangkaui Indonesia ke negara jiran termasuk Malaysia dan Singapura (Fujii et al. 2015).

Faktor lain yang mendorong kepada berlakunya masalah jerebu berkenaan adalah penebangan hutan untuk tujuan pembalakan dan pembukaan tanah untuk pertanian dan pembangunan (Norela et al. 2013). Penebangan 
hutan secara berleluasa akan menyebabkan pengurangan jumlah oksigen di sesuatu tempat berkenaan dan turut mengakibatkan gas karbon dioksida terperangkap dalam lapisan bumi dan tidak mampu diserap oleh tumbuhtumbuhan (Shaharuddin 1998).

Seterusnya, pertambahan kuantiti kenderaan bermotor telah menyumbang kepada berlakunya pencemaran udara terutama di kawasan bandar dengan peningkatan bahan pelepasan daripada kenderaan bermotor. Kenderaan yang menggunakan tenaga fosil seperti minyak petrol dan diesel mengeluarkan asap yang menyebabkan terjadinya pembebasan gas seperti karbon monoksida $(\mathrm{CO})$ dan sulfur dioksida $\left(\mathrm{SO}_{2}\right)$ (Mahmud \& Ab Llah 2010; Soleiman et al. 2003). Gas pencemar berkenaan merupakan bahan terampai yang memenuhi ruang udara dan terperangkap dalam lapisan bumi kerana tidak dapat dibebaskan ke atmosfera. Hal yang demikian menyebabkan asap memenuhi ruang udara dan seterusnya mengakibatkan terjadinya fenomena jerebu (Dominick et al. 2012). Penggunaan bahan api fosil juga sukar untuk disekat kerana sumber bahan api berkenaan adalah lebih murah dan mudah didapati berbanding tenaga nuklear dan bahan api yang lain. Selain daripada fenomena jerebu, pembebasan asap kenderaan turut menyebabkan berlakunya kejadian hujan asid.

Di samping itu, faktor lain yang turut menyumbang kepada fenomena jerebu adalah peningkatan kegiatan industri yang semakin rancak dan tidak terkawal. Seperti yang diketahui, Malaysia banyak bergantung kepada bidang perindustrian dalam menjana pendapatan negara. Namun begitu, sikap tidak bertanggungjawab segelintir pengusaha kilang yang sewenang-wenangnya melepaskan asap daripada kilang mereka telah mengakibatkan berlakunya pencemaran udara. Pelepasan asap kilang yang tidak mengikut prosedur yang telah ditetapkan oleh kerajaan juga telah memburukkan lagi kesan pencemaran alam sekitar. Asap kilang mengandungi gas sulfur dioksida $\left(\mathrm{SO}_{2}\right)$ dan gas berkenaan merupakan gas yang beracun. $\mathrm{SO}_{2}$ boleh menyebabkan rasa tidak selesa pada laluan penafasan, batuk, sukar bernafas dan kanser paru-paru. Apabila gas berkenaan terlalu banyak berkumpul di atmosfera dan bercampur dengan gas-gas lain ia akan mengundang kepada berlakunya kejadian jerebu (Noor Azilawati 2007). Secara keseluruhan, pelbagai aktiviti antropogenik menyumbang kepada fenomena kejadian jerebu terutama kebakaran hutan yang merupakan faktor dominan yang menyebabkan peningkatan fenomena jerebu dan fenomena El Niño meningkatkan lagi kekerapan kejadian jerebu berlaku.

\section{KEPUTUSAN DAN PERBINCANGAN}

\section{KESAN KEJADIAN FENOMENA JEREBU}

Fenomena jerebu merupakan kesan daripada bahan pencemar udara iaitu zarah aerosol yang turut memberi impak terhadap jarak penglihatan (Xu et al. 2014). Keadaan berkenaan adalah disebabkan oleh zarah yang terdapat dalam asap jerebu iaitu $\mathrm{PM}_{2.5}, \mathrm{SO}_{2}, \mathrm{NO}_{2}$ dan $\mathrm{O}_{3}$ yang berupaya menyerap dan menyerakkan cahaya matahari. Jarak penglihatan yang rendah adalah pada waktu pagi berbanding pada waktu petang disebabkan oleh peratusan kelembapan dan kepekatan $\mathrm{PM}_{25}$ mempengaruhi jarak penglihatan (Xiao et al. 2011). Pengurangan jarak penglihatan memberi impak besar terhadap aktiviti harian dan ekonomi penduduk. Keadaan berkenaan menyukarkan aktiviti perkhidmatan udara dan laut. Sistem pengangkutan udara seperti kapal terbang dan kenderaan darat seperti kereta dan bas turut berisiko tinggi untuk menghadapi kemalangan akibat daripada fenomena jerebu. Ini berikutan penglihatan yang kabur menyebabkan pemandu tidak mampu mengagak dengan tepat jarak kenderaan lain yang berdekatan.

Selain daripada itu, jerebu juga memberi kesan kepada sektor pertanian. Keadaan asap jerebu yang kritikal turut memberi kesan terhadap tumbuhan untuk menjalankan proses fotosintesis. Ini berikutan aerosol yang tidak larut air melekat pada bahagian daun, ia boleh mengakibatkan pengurangan fotosintesis dengan hasil tanaman yang lebih rendah, pengurangan $\mathrm{CO}_{2}$ yang lebih rendah serta peningkatan dalam kesan rumah hijau. Kesannya tumbuhan menghadapi masalah untuk proses pendebungaan maka penghasilan buah akan berkurangan (Xu et al. 2014).

Di samping itu, fenomena jerebu turut memberi kesan kritikal terhadap kesihatan manusia terutama kepada golongan kanak-kanak dan warga tua. Asap atau gas beracun yang terkandung di dalam jerebu boleh menyebabkan pelbagai masalah kesihatan seperti hidung berair, batuk, keradangan pada mata, sakit tekak dan kesukaran untuk bernafas (Mu \& Zhang 2014). Bahan pencemar udara seperti $\mathrm{PM}_{2.5}$ boleh memberi kesan buruk terhadap kesihatan manusia berikutan keupayaannya untuk menembusi sehingga ke dalam peparu manusia (Khan et al. 2016). Warga tua, kanak-kanak (terutamanya di bawah lima tahun), pesakit asma serta radang paru-paru merupakan golongan yang berisiko tinggi untuk mendapat masalah kesihatan berikutan daripada kejadian jerebu (Anaman \& Ibrahim 2003). Selain itu, golongan petani dan buruh kasar yang terpaksa bekerja dalam keadaan yang terdedah kepada jerebu di kawasan terbuka turut berisiko tinggi terhadap penyakit akibat daripada kejadian jerebu (Shaharuddin 1998).

Jerebu juga memberi kesan terhadap aktiviti sosial dan ekonomi penduduk di sesuatu kawasan itu (Mu \& Zhang 2014; Othman et al. 2014). Hal berkenaan dapat dirasai oleh semua peringkat umur baik kanak-kanak mahupun orang dewasa. Orang dewasa sukar untuk menjalankan aktiviti harian mereka seperti kesukaran untuk pergi ke tempat kerja manakala bagi golongan kanak-kanak pula waktu persekolahan mereka turut terjejas sehingga terdapat beberapa buah sekolah yang terpaksa ditutup akibat daripada keadaan jerebu yang berterusan dan kualiti udara yang sangat kritikal. Menurut Mohd Shah (2006), negara yang bergantung kepada sektor pelancongan sebagai sumber utama ekonomi akan menghadapi masalah daripada sudut ekonomi. Ini disebabkan oleh pengurangan jumlah 
pelancong dan keadaan alam sekitrar yang menghalang pelancong daripada berkunjung ke negara berkenaan. Oleh itu, kejadian bencana alam seperti gempa bumi, letupan gunung berapi termasuk jerebu mampu memberikan impak negatif terhadap negara berkenaan.

\section{KESIMPULAN}

Secara kesimpulannya, daripada perspektif Islam dukhan ditakrifkan sebagai satu seksaan atau azab kepada manusia yang ingkar akan perintah Allah dan Rasul-Nya. Ia juga memberi peringatan kepada umat manusia bahawasa azab Allah sangat berat untuk ditanggung dan merupakan sesuatu yang pasti yang akan dikenakan terhadap mereka yang derhaka akan suruhan serta larangan-Nya. Sebagai hamba-Nya di muka bumi ini kita harus berwaspada dan berusaha meneguhkan keimanan agar kita dijauhkan daripada azab serta kemurkaan daripada Allah. Manakala, jika dilihat daripada sudut sains dan kajian masa kini, dukhan ataupun jerebu ditakrifkan sebagai suatu fenomena pencemaran alam yang terjadi disebabkan percampuran antara gas yang terbentuk pada ruang atmosfera bumi. Faktor yang menyebabkan ia berlaku adalah perbuatan manusia itu sendiri tanpa memikirkan kesan jangka panjang terhadap keadaan alam sekitar. Seterusnya, kesan daripada fenomena jerebu dapat dirasai oleh semua pihak baik masyarakat ataupun negara. Pelbagai usaha telah dijalankan oleh pihak kerajaan dalam langkah menangani masalah jerebu daripada berulang. Namun begitu, sifat segelintir manusia yang mudah terlupa dan leka akan tanggungjawabnya terhadap alam sekitar serta mementingkan keuntungan sendiri telah mengundang padah kepada negara dan masyarakat lain. Oleh itu, kesedaran yang berterusan adalah sangat penting dalam menjaga keharmonian dan kesejahteraan alam sekitar. Integrasi ilmu dan kefahaman sesuatu fenomena alam seperti contoh jerebu, ini haruslah dilihat dalam konteks yang holistik serta transdisiplin supaya ia dapat dihayati dan difahami dengan sebaiknya dan dapat memberi tauladan kepada manusia agar tidak melakukan kerosakan di muka bumi ini dengan sewenangnya-wenangnya kerana impak perbuatan manusia itu akan berbalik kepada manusia itu sendiri seperti kisah yang telah diceritakan di dalam al-Quran.

\section{PENGHARGAAN}

Pengarang ingin mengucapkan jutaan terima kasih kepada Universiti Kebangsaan Malaysia di atas tajaan kajian penyelidikan ini melalui dana Skim Geran Universiti Penyelidikan Topdown, Universiti Kebangsaan Malaysia (No. Geran TD-2016-001).

\section{RUJUKAN}

Abdul Rahman, K. 2002. Observation of PM10 readings in relation to forest fire events from ASMA's continuuous air quality monitoring stations. In World Conference on Land and Forest Fire Hazards. Kuala Lumpur. hlm. 155-170.
Al-Suyuti. 2000. Al-Dar Al-Mansur Fi Tafsir Al-Ma'sur Lubnan. Darul Kitab Ilmiah.

Anaman, K.A. \& Ibrahim, N. 2003. Statistical estimation of doseresponse functions of respiratory diseases and societal costs of haze-related air pollution in Brunei Darussalam. Pure and Applied Geophysics 160: 279-293.

Asy-Syahid Sayyid Qutb. 2000. Tafsir Fi Zilalil Quran Jilid 14 Kelantan. Pustaka Aman Press Sdn. Bhd.

Dominick, D., Juahir, H., Latif, M.T., Zain, S.M. \& Aris, A.Z. 2012. Spatial assessment of air quality patterns in Malaysia using multivariate analysis. Atmospheric Environment 60: 172-181.

Fakhruddin Muhammad bin Umar al-Razi. 2000. Tafsir Al-Kabir Lubnan. Darul Kitab Ilmiah.

Fuad Abdul Baqi. 2002. al-Mu'jam al-Mufahras Li Alfaz al-Quran al-Karim. Lubnan. Dar el-Marefah.

Fujii, Y., Tohno, S., Amil, N., Latif, M.T., Oda, M., Matsumoto, J. \& Mizohata, A. 2015. Annual variations of carbonaceous $\mathrm{PM}_{2.5}$ in Malaysia: Influence by Indonesian peatland fires. Atmospheric Chemistry and Physics 15: 13319-13329.

Goudie, A.S. 2014. Desert dust and human health disorders. Environment International 63: 101-113.

Ibnu Katsir. 2003. Malapetaka Menjelang Hari Kiamat. Kuala Lumpur: Darul Fajar.

Ibnu Manzur. 2012. Lisan al-Arab Lubnan. Dar Sader Publishers. Imam Muhammad bin Ali bin Muhammad Asy-Syaukani. 2012. Tafsir Fathu Qadir. Jakarta. Pustaka Azzam.

Keywood, M.D., Ayers, G.P., Gras, J.L., Boers, R. \& Leong, C.P. 2003. Haze in Klang Valley of Malaysia. Atmospheric Chemistry and Physics 3: 591-605.

Khan, M.F., Sulong, N.A., Latif, M.T., Nadzir, M.S.M.,Amil, N., Hussain, D.F.M., Lee, V., Hosaini, P.N., Shaharom, S., Yusoff, N.A.Y.M., Hoque, H.M.S., Chung, J.X., Sahani, M., Mohd Tahir, N., Juneng, L., Maulud, K.N.A., Abdullah, S.M.S., Fujii, Y., Tohno, S. \& Mizohata, A. 2016. Comprehensive assessment of $\mathrm{PM}_{2.5}$ physicochemical properties during the Southeast Asia dry season (southwest monsoon). Journal of Geophysical Research: Atmospheres 121(14): 589-611.

Lee, J.S.H., Jaafar, Z., Tan, A.K.J., Carrasco, L.R., Ewing, J.J., Bickford, D.P., Webb, E.L. \& Koh, L.P. 2016. Towards clearer skies: Challenges in regulating transboundary haze in Southeast Asia. Environmental Science and Policy 55: 87-95.

Li, R., Gong, J., Zhou, J., Sun, W. \& Ibrahim, A.N. 2015a. Multi-satellite observation of an intense dust event over Southwestern China. Aerosol and Air Quality Research 15: 263-270.

Li, Y., Fu, H., Wang, W., Liu, J., Meng, Q. \& Wang, W. 2015 b. Characteristics of bacterial and fungal aerosols during the autumn hae days in Xi' an, China. Atmospheric Environment 122: 439-447.

Mahmud, M. \& Ab Llah, I.H. 2010. Pencemaran udara di Bukit Rambai, Melaka sewaktu peristiwa jerebu tahun 2005. Malaysian Journal of Society and Space 6(3): 30-39.

Mohd Shah, A. 2006. Jerebu: Apa Anda Perlu Tahu. Johor Bahru: ABS Tinta.

Mu, M. \& Zhang, R.H. 2014. Addressing the issue of fogand haze: A promising perspective from meteorogical science and technology. Science China: Earth Science 57(1): 1-2.

Muhammad Hisham Kabbani. 2003. The Approach of Armageddon. America: Council of America.

Noor Azilawati, M.A. 2007. Pencemaran Terhadap Atmosfera. Kuala Lumpur: Cipta Publishing. 
Norela, S., Saidah, M.S. \& Mahmud, M. 2013. Chemical composition of the haze in Malaysia 2005. Atmospheric Environment 77: 1005-1010.

Othman, J., Sahani, M., Mahmud, M. \& Sheikh Ahmad, M.K. 2014. Transboundary smoke hae pollution in Malaysia: Inpatient health impacts and economic valuation. Environ. Pollut. 189: 194-201.

Sa'̄id Hawwā. 1985. Al-Asās fī al-Tafsīr Jilid 9 Kaherah: Darussalam.

Salahuddin bin Abdullah \& Omar bin Khaid. 2009. Tafsir Mubin Juzzuk 26-30. Kuala Lumpur: Dewan Bahasa dan Pustaka.

Shaharuddin, A. 1998. El Niño 1998 dan kesannya terhadap perubahan cuaca di Malaysia. Seminar FSSK Ke-3, 18-19 Ogos. Bangi: Universiti Kebangsaan Malaysia.

Soleiman, A., Othman, M., Azizan, A.S., Sulaiman, N.M. \& Rodojeric, M. 2003. The occurance of haze in Malaysia: A case study in an urban industrial area. Pure and Applied Geophysics 160: 221-238.

Syaikh Abdul Malik bin Abdul Karim Amrullah (HAMKA). 1981. Tafsir Al-Azhar Juzuk 25 Surabaya. Yayasan Latimojong.

Tam, E., Miike, R., Labreze, S., Sutton, A.J., Elias, T., Davis, J., Chen, Y.L., Tantira, K., Dockery, D. \& Avol, E. 2016. Volcanic air pollution over the Island of Hawai'i: Emission, dispersal and composition. Association with respiratory symptoms and lung function in Hawai'i Island school children. Environment International 92-93: 543-552.

Xiao, Z.M., Zhang, Y.F., Hong, S.M., Bi, X.H., Jiao, L., Feng, Y.C. \& Wang, Y.Q. 2011. Estimation of the main factors influencing haze, based on longterm monitoring campaign in Hangzhou, China. Aerosol and Air Quality Research 11: 873-882.

Xu, J., Tai, X., Betha, R., He, J. \& Balasubramaniam, R. 2014. Comparison of physical and chemical properties of ambient aerosols during the 2009 haze and non-haze periods in Southeast Asia. Environmental Geochemistry and Health 37(5): 831-841.
Yong, D.L. \& Peh, K.S.H. 2014. South-East Asia's forest fires: Blazing the policy trail. Oryx 50(2): 207-212.

Zhang, Q., Quan, J., Tie, X., Li, X., Liu, Q., Gao, Y. \& Zhao, D. 2015. Effects of meteorology and secondary particle formation on visibility during heavy haze events in Beijing, China. Science of the Total Environment 502: 578-584.

Ahmad Yunus Mohd Noor*

Jabatan Usuluddin \& Falsafah, Fakulti Pengajian Islam

Universiti Kebangsaan Malaysia

43600 UKM Bangi, Selangor Darul Ehsan

Malaysia

Nor Azilah Abdul Wahab

Pusat Pengajian Sains Sekitaran dan Sumber Alam

Fakulti Sains \& Teknologi

Universiti Kebangsaan Malaysia

43600 UKM Bangi, Selangor Darul Ehsan

Malaysia

Asmilyia Mohd Mokhtar

Jabatan Bahasa al-Quran, CELPAD

Universiti Islam Antarabangsa

50728 Kuala Lumpur, Wilayah Persekutuan

Malaysia

*Pengarang untuk surat-menyurat; email: a_yunus@ukm.edu.my

Diserahkan: 1 Jun 2017

Diterima: 3 Ogos 2017 